\title{
EKG i allmennpraksis - kvaliteten kan forbedres
}

\author{
Et EKG må tas riktig og tolkes korrekt for at undersøkelsen skal ha verdi. Vi foreslår et minikurs for allmenn- \\ leger i spesialisering og et tettere samarbeid med spesialisthelsetjenesten om tolkingen.
}

En EKG-undersøkelse er et nyttig verktøy ved utredning og oppfølging av pasienter med hjerte- og karsykdommer. Det er en billig og rask undersøkelse som passer godt i allmennpraksis, men den krever opplæring for å kunne brukes optimalt i den kliniske hverdagen.

I en studie, publisert i Hjerteforum i 2014 (1), undersøkte vi omfanget av og kvaliteten på EKG-bruk blant allmennleger i Akershus. Dette ble gjort ved hjelp av et spørreskjema samt analyse av tolkinger av innsendte EKG-utskrifter. Til tross for noen begrensninger (datainnsamling fra kun ett fylke og moderat oppslutning) ga studien noen interessante resultater.

De fleste allmennleger i Akershus hadde og brukte sitt eget EKG-apparat. Den negative prediktive verdien av allmennlegers tolking var høy ( $95 \%$ av antatt normale EKG-er var uten patologiske funn), mens det var betydelig dårligere treffsikkerhet når det gjaldt å tolke et EKG som var unormalt $(16 \%$ av tolkingene hadde avvik av antatt klinisk betydning). Det var kun $43 \%$ av allmennlegene som oppga at de tidvis søkte tolkingsassistanse hos spesialist. Dette synes vi er bekymringsfullt, da feilene som ble gjort, omfattet klinisk viktige diagnoser som atrieflimmer og gamle hjerteinfarkter.

\section{Strengere krav}

I dag er det ingen spesifiserte krav til EKGtaking og -tolking i spesialistutdanningen for allmennleger - dette er bare én av 54 praktiske ferdigheter utdanningen omfatter (2). Kravet for spesialiteten er underskrift fra spesialister i allmennmedisin om at legen behersker minst 30 av de 54 ferdighetene. For en rekke andre ferdigheter kreves deltakelse på kurs med kursprøve.

Vi tror at innføring av tilsvarende krav for utføring og tolking av EKG vil bedre kvaliteten på allmennlegenes bruk av undersøkelsen. Erfaringene både hos allmennleger og spesialister er at EKG-apparatenes innebygde tolkingsprogrammer ennå ikke er gode nok til å erstatte legens tolking $(3,4)$.

\section{Kurstilbud}

Tidligere fantes det et femdagers kurs i EKG for allmennleger, som etter dette fikk refusjonstakst for taking og tyding av EKG. Dette kurset var nok for omfattende, og refusjonstaksten er avviklet. Med et mindre kurs, ideelt sett i regi av Legeforeningen, kunne man konsentrere seg om vanlige og praktisk viktige EKG-ferdigheter: Korrekt oppkobling og innstilling

\section{«l dag er det ingen spesifiserte krav til EKG-taking og -tolking i spesialistutdanningen for allmennleger»}

av apparatet samt basale tolkingsferdigheter. Gjenkjenning av gamle infarkter, atrieflimmer, venstre ventrikkel-hypertrofi og grenblokk anser vi som minimumskrav til allmennleger, da disse er vanlig forekommende og tilstedeværelse kan ha betydning for behandlingsvalget.

Et slikt kurs kunne være todelt, for eksempel med et firetimers nettbasert forkurs som avrundes med tre øvelsestimer på en regional samling for å gjennomgå tolkinger og vanlige fallgruver.

\section{Samarbeid med spesialist}

Under halvparten av de spurte allmennlegene oppga at de samarbeidet med spesialister om EKG-tolking. Vi mener det burde være lav terskel for å få tolkehjelp fra spesialist. Noen har avtale om slik hjelp, men dette er det ofte vanskelig å få organisert ved sykehus eller hos praktiserende spesialist. En egen takst som belønner EKG-tolkingsassistanse av spesialist, ville trolig stimulere til opprettelse eller utvidelse av en slik tjeneste. Det er også lett å se for seg et effektivt system med digital overføring av EKG til spesialist og rask retur av kvalifisert tolking.

Vi oppfordrer spesialitetskomiteen for allmennmedisin og Allmennlegeforeningen til å ta initiativ til at det blir laget et enkelt, målrettet EKG-kurs for spesialiteten og til å etablere enkle samarbeidsopplegg med spesialisteri indremedisin/hjertesykdommer om tolking, for eksempel gjennom innføring av en egen takst for tolkingsassistanse.

\section{Eivind Verley Kvittingen \\ Bjørn Gjelsvik \\ Knut Gjesdal \\ knut.gjesdal@medisin.uio.no}

Eivind Verley Kvittingen (f. 1984) er lege ved Molde sykehus fra høsten 2015.

Forfatter har fylt ut ICMJE-skjemaet og oppgir ingen interessekonflikter.

Bjørn Gjelsvik (f. 1949) er ph.d. og forsker, lærer og veileder ved Avdeling for allmennmedisin, Universitetet i Oslo. Han er også fastlege i Bærum.

Forfatter har fylt ut ICMJE-skjemaet og oppgir ingen interessekonflikter.

Knut Gjesdal (f. 1944) er professor emeritus. Han arbeider ved Hjertemedisinsk avdeling, Oslo universitetssykehus, Ullevål, og Institutt for klinisk medisin, Universitetet i Oslo.

Forfatter har fylt ut ICMJE-skjemaet og oppgir følgende interessekonflikter: Han er EKG-konsulent ved Fürst Medisinsk Laboratorium (deltidsengasjement) og har produsert et kurshefte i EKG for AstraZeneca.

\footnotetext{
Litteratur

1. Kvittingen EV, Gjelsvik B, Gjesdal K. EKG i allmennpraksis: behov for økt samarbeid med spesialisthelsetjenesten. Hjerteforum 2014; 27: 42-7.

2. Attest for praktiske ferdigheter i allmennmedisin. Helsedirektoratet 2015

https://helsedirektoratet.no/godkjenning-ogautorisasjon/spesialistgodkjenning/lege/ allmennmedisin (28.2.2015).

3. Guglin ME, Thatai D. Common errors in computer electrocardiogram interpretation. Int J Cardiol 2006; 106: 232-7.

4. Estes NA 3rd. Computerized interpretation of ECGs: supplement not a substitute. Circ Arrhythm Electrophysiol 2013; 6: 2-4
}

Mottatt 7.3. 2015 og godkjent 7.4. 2015. Redaktør Kari Tveito.

Publisert først på nett. 